\title{
Effects of divergent selection for leg weakness on muscle and bone characteristics in Duroc swine*
}

\author{
DD Draper ${ }^{1}, \mathrm{MF}$ Rothschild ${ }^{2}$, LL Christian ${ }^{2}$ \\ ${ }^{1}$ Department of Veterinary Anatomy, Iowa State University, Ames 50011, IA ; \\ 2 Department of Animal Science, Iowa State University, Ames, IA 50011, USA
}

(Received 9 January 1992; accepted 4 May 1992)

\begin{abstract}
Summary - The dimensions and weights of front leg muscles, tendons, and bones were determined in 44 gilts that were offspring of three Duroc lines from a five-generation divergent-selection experiment on leg weakness. Lines were low, control, and high, with the low line having the greatest leg weakness and the high-line having the least leg weakness. At a slaughter weight of approximately $118 \mathrm{~kg}$, the right front leg was removed from the carcasses of 14 low-, 16 control-, and 14 high-line gilts. Each intrinsic muscle was dissected from origin to insertion, removed from the leg, and measured for total length and weight. The skeleton of the front leg was disarticulated so that each bone was freed and thoroughly cleaned of muscle remnants and connective tissue. The shoulder and elbow joints were scored for the presence of osteochondral lesions. Each bone was weighed, and various dimensional traits were measured. The model used to analyze the data included the effects of line, sire within line, and weight as a covariate. The biceps brachii muscle weight and length were significantly greater in low-line pigs than in control- or high-line pigs $(P<0.05)$. Collectively, the forearm extensor weights were significantly greater in low-line pigs than in control- or high-line pigs $(P<0.05)$. The humeral and metacarpal bones were shorter in high-line pigs than in control- or low-line pigs $(P<0.05)$. The head of the humerus was wider and the angle of the head of the humerus was greater in high-line pigs than in control- or low-line pigs $(P<0.05)$. Divergent selection for differing degrees of leg soundness in Duroc swine appears to be associated with major differences in front-leg bone and muscle lengths and weights.
\end{abstract}

pigs / leg weakness / bone / muscle / selection

Résumé - Effets d'une sélection divergente pour la qualité des aplombs sur des caractéristiques osseuses et musculaires chez le porc Duroc. Les dimensions et poids des muscles, tendons et os du train antérieur ont été mesurés chez 44 porcs descendant

\footnotetext{
* Journal Paper No J-13958 of the Iowa Agriculture and Home Economics Experiment Station, Ames, IA, Projects No 1901 and 2798.
} 
de 3 lignées Duroc sélectionnées pendant 5 générations pour la faiblesse des membres, une lignée basse (faible), une lignée haute (solide) et une lignée témoin. À un poids d'abattage de $118 \mathrm{~kg}$, les membres antérieurs droits ont été prélevés sur les carcasses de 14 porcs appartenant à la lignée basse, de 16 porcs de la lignée-témoin et de 14 porcs appartenant à la lignée haute. Chaque muscle a été disséqué depuis l'origine jusqu'à l'insertion, enlevé du membre et mesuré pour sa longueur totale et son poids. Le squelette du membre antérieur a été désarticulé et chaque os a été séparé de ses attaches, puis débarrassé des muscles et du tissu conjonctif. Les articulations de l'épaule et du coude ont été notées pour la présence de lésions ostéochondrales. Chaque os a été pesé et diverses caractéristiques ont été mesurées. Le modèle utilisé pour l'analyse des données comprenait les effets suivants: lignée, père intra-lignée et poids comme covariable. La longueur et le poids du muscle biceps brachii des porcs de la lignée basse étaient significativement supérieurs à ceux des porcs des autres lignées $(\mathrm{P}<0.05)$. Au total, le poids des muscles extenseurs de l'avant-bras des porcs de la lignée basse était significativement supérieur à ceux des porcs témoins et de la lignée haute $(\mathrm{P}<0.05)$. L'humérus et le métacarpe étaient plus courts dans la lignée haute par rapport aux autres lignées $(\mathrm{P}<0.05)$. La tête et l'angle de l'humérus étaient plus grands chez les porcs de la lignée haute que chez les porcs des autres lignées $(\mathrm{P}<0.05)$. La sélection divergente pour différents degrés de faiblesse du train antérieur chez le porc Duroc semble être associée à d'importantes différences dans la longueur et le poids des os et des muscles du membre antérieur.

porc / faiblesse des membres / os / muscle / sélection

\section{INTRODUCTION}

Leg-weakness disorders are a serious and widespread problem in the swine industry. The term leg weakness has been used to describe a syndrome that involves a variety of defects in shape, posture, structure, and function of the joints, legs, or feet of pigs. The musculoskeletal disorder contributes to economic losses for the seedstock producer and the commercial operator (Grøndalen, 1974c; Reiland et al, 1978; Bereskin, 1979; Wilson, 1980).

Factors contributing to leg weakness may include nutritional imbalances (Nielsen, 1973; Grøndalen, 1974a, d; Reiland et al, 1978, van der Wal et al, 1982), skeletal lesions (Grøndalen, 1974 a, c; Goedegebuure et al, 1980 a, b; van der Valk et al, 1980; Wilson, 1980; van der Wal et al, 1987), microbial diseases (Christensen, 1953; Duthie and Lancaster, 1964; Grøndalen, 1974a ; Lawrisuk et al, 1987), and trauma (Nakano and Aherne, 1988). In addition, it has been demonstrated repeatedly that heredity plays a significant role in the development and appearance of porcine leg weakness (Reiland et al, 1978; Bereskin, 1979; Drewry, 1979; Wilson, 1980; Webb et al, 1983 ; Draper et al, 1988; Rothschild and Christian, 1988). Three lines of Duroc swine that differ in their degree of leg weakness were developed from a 5-generation divergent-selection experiment (Rothschild and Christian, 1988). Previous research, which examined cross-sectional-area differences in muscles and bones, had suggested that selection for differing degrees of leg weakness had caused significant changes in the anatomy of these pigs (Draper et al, 1991). The pigs produced from this experiment were unique models in which to study further the relationship between bone and muscle structure and leg weakness. The purpose 
of the study was to determine if differences existed in the weights and lengths of bones and muscles of the front legs of gilts from 3 Duroc lines that differ in degree of leg weakness.

\section{MATERIALS AND METHODS}

The animals used for this experiment were obtained from the Bilsland Memorial Swine Breeding Farm, Madrid, Iowa. They consisted of 44 gilts chosen randomly from 3 lines of Duroc swine that differed genetically in the expression of leg weakness. The origin of these 3 lines of pigs has been reported by Rothschild and Christian (1988). Using a 9-point scale, the 3 lines differed greatly in their scores for front leg structure. In this study, pigs from generation 5 of the divergent-selection experiment were used. The low-line group of 14 gilts exhibited severe front leg weakness. The high-line group of 14 gilts possessed superior front-leg structure and did not exhibit leg weakness, and the control-line group contained 16 pigs that were average in front-leg structure and expressed little or no leg weakness.

The 44 gilts used in this study were part of the entire group of progeny which were weaned at 6 weeks of age and confined to enclosed pens with concrete floors and flush gutters. A $16 \%$ corn-soybean meal grower ration containing appropriate levels of vitamins and minerals was fed to the gilts on a free choice basis. Water was always available. When the gilts reached $100-105 \mathrm{~kg}$ of liveweight, they were moved to outdoor lots with concrete floors. The gilts were scored for front-leg weakness within 7 days after being placed outdoors. The scoring procedures have been described elsewhere (Rothschild and Christian, 1988).

The gilts were killed in random order at the Iowa State University Meat Laboratory within 3 weeks of having been scored. Each weighed approximately $118 \mathrm{~kg}$. The gilts were from 17 sires and 42 litters. The number of gilts from each sire was proportional to the number of gilts available in each sire progeny group. Gilts used in this study were chosen at random within line with the restriction that each selected gilt's soundness score was within one standard deviation of the mean for its line. This selection procedure assured that the gilts slaughtered were representative of their line.

Carcass measurements including longissimus dorsi, area, carcass length, and average backfat thickness were taken after pigs were slaughtered. Subsequently the right front leg was removed from the carcass of each gilt and stored in a walkin cooler until processed. Within $48 \mathrm{~h}$ of slaughter, the intrinsic muscles of each limb were dissected from their origin and insertion; they were immediately weighed and their lengths were recorded. The front-leg skeleton was disarticulated so that each bone could be thoroughly cleaned of muscle and connective tissue. The head and condyles of the humerus and the proximal surfaces of the radius and una were scored for the presence of osteochondral lesions as described in Goedegebuure et al (1988). Scores of 0 to 3 were assigned, with a 0 representing no lesion on the articular surface, a 1 a slight discoloration and thinning of the cartilage, and a 3 severe erosions of the articular surface. Surfaces of designated bones were scored by 3 observers, working independently, who had no knowledge of the line of pig to which a bone belonged. The length and width of each bone was measured with a caliper and the width of the neck of the scapula and the head of the humerus were 
measured and recorded. The angle at which the head was attached to the shaft of the humerus was determined and recorded. The radius and ulna were weighed together because they are partly fused in the pig. The carpal bones were weighed as one unit because they are held together by numerous ligaments.

Analysis-of-variance procedures were used to analyse the data. The statistical model used was:

$y_{i j k}=\mu+l_{i}+s_{i j}+b\left(x_{i j k}\right)+e_{i j k}$ where:

$y_{i j k}=$ observed value for the muscle or bone trait,

$\mu=$ overall mean,

$l_{i}=i$ th line (high, control or low),

$s_{i j}=j$ th sire in the $i$ th line (assumed random),

$b\left(x_{i j k}\right)=$ covariate for weight at slaughter and

$e_{i j k}=$ random error with mean zero and variance $\sigma^{2}$.

Sire within line was used as the error term to test line effects. Since 42 litters were represented by a total of 44 pigs, dam (litter) was not included. Person scoring for the bone and structure scores was not included in the model since previous analyses demonstrated it was not a significant source of variation. Least square means were computed with sire within line used to compute the standard errors. Student's $t$-test was used to compare all possible means when overall line effects were significant in the analysis of variance. This test is less conservative that some mean separation tests.

\section{RESULTS}

The front soundness score means for the gilts representing the high, control and low lines were $7.79 \pm 0.20,5.19 \pm 0.25$ and $3.41 \pm 0.19$, respectively. The values demonstrate the pigs included were representative of their respective lines (Rothschild and Christian, 1988). In table I, differences among the lines for carcass traits are presented. Low-line pigs had significantly $(P<0.05)$ longer carcasses than the control-line pigs but were not significantly longer than carcasses of the high-line pigs. There were no differences in carcass yield or loin eye area between the 3 lines. There was a tendency for low-line pigs to have less $(P<0.09)$ average backfat than high-line pigs.

Differences were found in the weights of some muscles of the arm and forearm. The mean values for muscle weights are summarized in table II). In the arm, the biceps brachii weighed more $(P<0.05)$ in low-line pigs than in control- or highline pigs. There were no line differences detected for weights of the other brachial muscles. Several line differences were observed in weights of extensor muscles of the forearm. Both the extensor carpi radialis and lateral digital extensor muscles were heavier in low-line pigs than in control- or high-line pigs $(P<0.05)$. Similarly, the total weight of extensor muscles of the forearm was heavier in low-line pigs than in control- or high-line pigs $(P<0.05)$. There were no line differences in weights of flexor muscles of the forearm, although there was a trend $(P<0.06)$ for the deep digital flexor to weigh less in low-line pigs than in high-line pigs.

Several significant line differences were found in the lengths of muscles of the shoulder, arm, and forearm regions (table III) of the front leg. In the shoulder region, 
Table I. Mean ${ }^{a}$ of carcass traits of Duroc gilts selected for different degrees of leg soundness.

\begin{tabular}{|c|c|c|c|c|c|c|}
\hline \multirow[t]{2}{*}{ Trait } & Low-line & $(\mathrm{N}=14)$ & Control-line & $(\mathrm{N}=16)$ & High-line & $(\mathrm{N}=14)$ \\
\hline & $X$ & $S E$ & $X$ & $S E$ & $X$ & $S E$ \\
\hline Yield (\%) & 75.17 & 0.71 & 72.51 & 0.61 & 74.24 & 0.61 \\
\hline $\begin{array}{l}\text { Length }(\mathrm{cm}) \\
\text { Backfat }\end{array}$ & $87.6^{\mathrm{b}}$ & 0.10 & $85.3^{c}$ & 0.53 & $85.9^{\mathrm{bc}}$ & 0.56 \\
\hline $\begin{array}{l}\text { average }(\mathrm{cm}) \\
\text { Loin eye }\end{array}$ & 3.00 & 0.15 & 3.25 & 0.13 & 3.53 & 0.13 \\
\hline area $\left(\mathrm{cm}^{2}\right)$ & 38.97 & 1.22 & 39.48 & 1.22 & 39.48 & 1.22 \\
\hline
\end{tabular}

${ }^{a}$ Least squares estimates; ${ }^{b c}$ Means within a row without a common superscript differ significantly $(P<0.05)$.

the subscapularis muscle was longer in low-line pigs than it was in control-line pigs $(P<0.01)$ but not significantly different from high-line pigs. In the arm region, both the biceps brachii $(P<0.05)$ and the tensor fascia antibrachii $(P<0.01)$ were longer in low-line pigs than they were in control- or high-line pigs. Only one significant line difference was observed in length of forearm muscles. The common digital extensor muscle was shorter in high-line pigs than in control- or low-line pigs $(P<0.05)$. In addition, there was a tendency $(P<0.06)$ for the extensor carpi radialis to be longer in low-line pigs than it was in high-line pigs.

Some osteochondral lesions were observed on the articular cartilage of the proximal and distal extremities of the humerus and the proximal extremities of the radius and ulna (data not shown). There were no significant differences between lines, however, in the occurrence of osteochondrosis. The worst osteochondral lesions were found on the distal humerus. The least severe lesions were on the proximal humerus.

Weight and dimension values for various bones of the front leg are listed in table IV. There were no significant line differences in the weights of the bones of the front leg, although there was a trend $(P<0.06)$ for the scapula to be heavier in high-line than in low- or control-line pigs. In contrast to weight values of the bones, there were several significant line differences in bone lengths. The humerus was shorter in high-line pigs than it was in control- or low-line pigs $(P<0.05)$. Furthermore, the metacarpal bones were significantly shorter in high-line pigs than they were in control- or low-line pigs $(P<0.01)$. In addition, the ulna tended to be shorter in high-line pigs than it was in low-line pigs $(P<0.07)$. As for other dimensions, the width of the scapula neck was less in control-line than in low- line or high-line pigs $(P<0.05)$. Also, it was observed that high-line pigs had a thicker scapula than did control- or low line pigs $P<0.01$ ). There were several dimensions of the humerus that differed between lines. The head of the humerus was wider in high-line pigs than in low-line pigs $(P<0.05)$, and the angle at which the head attached to the shaft of the humerus was greater in high-line than in control- or lowline pigs $(P<0.05)$. With the exception of bone length, there were no differences between lines in the dimensions of the bones distal to the elbow. 
Table II. Mean weights ${ }^{\mathrm{a}}$ of intrinsic muscles of the right front legs of Duroc gilts selected for different degrees of leg soundness.

\begin{tabular}{|c|c|c|c|c|c|c|}
\hline \multirow{2}{*}{$\begin{array}{l}\text { Muscle } \\
(g)\end{array}$} & \multicolumn{2}{|c|}{ Low-line $(\mathrm{N}=14)$} & \multirow{2}{*}{$\frac{\text { Control-line }}{\bar{X}}$} & \multirow{2}{*}{$\frac{(\mathrm{N}=16)}{S E}$} & \multirow{2}{*}{$\frac{\text { High-line }}{\bar{X}}$} & \multirow{2}{*}{$\begin{array}{c}(\mathrm{N}=14) \\
S E\end{array}$} \\
\hline & $\bar{X}$ & $S E$ & & & & \\
\hline \multicolumn{7}{|l|}{ Arm } \\
\hline Biceps brachii & $94.75^{\mathrm{b}}$ & 3.24 & $84.64^{\mathrm{c}}$ & 2.53 & $81.81^{\mathrm{c}}$ & 2.57 \\
\hline Brachialis & 119.30 & 5.75 & 115.64 & 4.49 & 110.40 & 4.56 \\
\hline Coracobrachialis & 26.33 & 1.92 & 23.28 & 1.48 & 25.00 & 1.49 \\
\hline Triceps brachii & 953.56 & 34.96 & 926.98 & 27.29 & 890.63 & 27.71 \\
\hline Tensor fascia & & & & & & \\
\hline antebrachii & 71.32 & 4.86 & 69.77 & 3.79 & 70.84 & 3.85 \\
\hline \multicolumn{7}{|l|}{ Forearm } \\
\hline $\begin{array}{l}\text { Flexor carpi } \\
\text { ulnaris }\end{array}$ & 21.94 & 1.08 & 22.13 & 0.84 & 21.73 & 0.85 \\
\hline $\begin{array}{l}\text { Flexor carpi } \\
\text { radialis }\end{array}$ & 11.73 & 0.97 & 13.74 & 0.76 & 12.06 & 0.79 \\
\hline $\begin{array}{l}\text { Superficial } \\
\text { digital flexor }\end{array}$ & 58.46 & 3.50 & 65.91 & 2.73 & 61.81 & 2.77 \\
\hline $\begin{array}{l}\text { Deep digital } \\
\text { flexor }\end{array}$ & 108.58 & 4.34 & 117.84 & 3.39 & 123.80 & 3.44 \\
\hline $\begin{array}{l}\text { Extensor carpi } \\
\text { radialis }\end{array}$ & $134.64^{\mathrm{b}}$ & 4.89 & $116.99^{c}$ & 3.81 & $121.50^{\mathrm{c}}$ & 3.87 \\
\hline $\begin{array}{l}\text { Common digital } \\
\text { extensor }\end{array}$ & 54.26 & 2.20 & 50.29 & 1.72 & 48.04 & 1.74 \\
\hline $\begin{array}{l}\text { Lateral digital } \\
\text { extensor }\end{array}$ & $33.21^{\mathrm{b}}$ & 1.32 & $29.11^{\mathrm{c}}$ & 1.03 & $28.10^{\mathrm{c}}$ & 1.04 \\
\hline $\begin{array}{l}\text { Long digital } \\
\text { abductor } \\
\text { Total extensor }\end{array}$ & 7.27 & 0.39 & 7.80 & 0.31 & 7.85 & 0.31 \\
\hline $\begin{array}{l}\text { Total extensor } \\
\text { weight }\end{array}$ & $229.44^{b}$ & 7.29 & $204.66^{\mathrm{c}}$ & 5.87 & $205.49^{c}$ & 5.80 \\
\hline $\begin{array}{l}\text { Total flexor } \\
\text { weight }\end{array}$ & 214.01 & 7.26 & 232.56 & 5.66 & 230.86 & 5.94 \\
\hline
\end{tabular}

a Least squares estimates; ${ }^{\text {bc }}$ Means within a row without a common superscript differ significantly $(P<0.05)$.

\section{DISCUSSION}

Duroc pigs that genetically differed in their expression of leg weakness after five generations of selection were found to differ also in several traits of bones and muscles of the front leg. Selection of pigs with different degrees of leg weakness was associated with differences in carcass length and leanness. This increased leanness in low line pigs was previously seen by Rothschild et al (1988). Selection of pigs with different degrees of leg weakness was also associated with changes in length and other dimensions of some bones and differences in muscle weights and lengths. These differences occurred in the absence of differential osteochondrosis in the lines. The differences were not likely to have been associated with diet or management 
Table III. Mean lengths ${ }^{\mathrm{a}}$ of intrinsic muscles of the right front legs of Duroc gilts selected for different degrees of leg soundness.

\begin{tabular}{|c|c|c|c|c|c|c|}
\hline \multirow{2}{*}{$\begin{array}{l}\text { Muscle } \\
\text { (cm) }\end{array}$} & \multicolumn{2}{|c|}{ Low-line $(\mathrm{N}=14)$} & \multicolumn{2}{|c|}{ Control-line $(\mathrm{N}=16)$} & \multicolumn{2}{|c|}{ High-line $(\mathrm{N}=14)$} \\
\hline & $\bar{X}$ & $S E$ & $\bar{X}$ & $S E$ & $\bar{X}$ & $S E$ \\
\hline \multicolumn{7}{|l|}{ Shoulder } \\
\hline Deltoideus & 19.26 & 1.13 & 18.75 & 0.87 & 21.06 & 0.87 \\
\hline Supraspinatus & & & & & & \\
\hline and infraspinatus & 25.21 & 0.55 & 24.50 & 0.43 & 25.32 & 0.43 \\
\hline Teres minor & 14.87 & 0.61 & 14.75 & 0.48 & 14.16 & 0.49 \\
\hline Subscapularis & $18.40^{\mathrm{b}}$ & 0.38 & $16.59^{\mathrm{c}}$ & 0.29 & $17.62^{\mathrm{bc}}$ & 0.30 \\
\hline Teres major & 21.38 & 0.48 & 20.73 & 0.37 & 21.24 & 0.38 \\
\hline \multicolumn{7}{|l|}{ Arm } \\
\hline Biceps brachii & $19.56^{\mathrm{b}}$ & 0.41 & $18.21^{\mathrm{c}}$ & 0.32 & $17.91^{\mathrm{c}}$ & 0.33 \\
\hline Brachialis & 17.18 & 0.35 & 16.58 & 0.27 & 16.53 & 0.27 \\
\hline Coracobrachialis & 11.51 & 0.78 & 10.42 & 0.55 & 10.65 & 0.53 \\
\hline Triceps brachii & 25.63 & 0.44 & 24.52 & 0.34 & 25.10 & 0.35 \\
\hline $\begin{array}{c}\text { Tensor fascia } \\
\text { antebrachii }\end{array}$ & $24.01^{\mathrm{b}}$ & 0.61 & $21.84^{\mathrm{c}}$ & 0.48 & $21.35^{\mathrm{c}}$ & 0.48 \\
\hline \multicolumn{7}{|l|}{ Forearm } \\
\hline $\begin{array}{l}\text { Flexor carpi } \\
\text { ulnaris }\end{array}$ & 17.10 & 0.40 & 17.06 & 0.31 & 16.54 & 0.32 \\
\hline $\begin{array}{l}\text { Flexor carpi } \\
\text { radialis }\end{array}$ & 15.01 & 0.47 & 15.60 & 0.36 & 14.77 & 0.38 \\
\hline $\begin{array}{l}\text { Superficial } \\
\text { digital flexor } \\
\text { Deep digital }\end{array}$ & 25.97 & 0.53 & 26.15 & 0.41 & 25.83 & 0.42 \\
\hline flexor & 33.70 & 0.65 & 33.57 & 0.51 & 32.79 & 0.51 \\
\hline $\begin{array}{l}\text { Extensor carpi } \\
\text { radialis }\end{array}$ & 25.12 & 0.37 & 24.45 & 0.29 & 23.83 & 0.29 \\
\hline $\begin{array}{l}\text { Common digital } \\
\text { extensor }\end{array}$ & $31.63^{\mathrm{d}}$ & 0.64 & $32.09^{\mathrm{d}}$ & 0.50 & $29.77^{\mathrm{e}}$ & 0.51 \\
\hline $\begin{array}{l}\text { Lateral digital } \\
\text { extensor }\end{array}$ & 29.71 & 0.72 & 29.71 & 0.56 & 28.46 & 0.57 \\
\hline
\end{tabular}

${ }^{a}$ Least squares estimates; ${ }^{b c}$ Means within a row without a common superscript differ significantly $(P<0.01)$; de Means within a row without a common superscript differ significantly $(P<0.05)$.

procedures in as much as all lines received the same ration and co-habited the same environment. Thus, it is reasonable to imply that the selection process for leg weakness has increased the structural differences within the front leg.

The relationship between shorter bones and leg soundness, as observed in highline pigs, has not been reported previously and was the first indication of nonpathological involvement of skeletal structures in leg weakness. Other investigators have reported on the relationship between leg weakness and osteochondrosis in pigs, but results varied, depending on differences in front and hind legs, breed, and age (Thurley, 1969; Grøndalen, 1974 b, c; Goedegebuure et al, 1980b; van der Valk 
Table IV. Mean ${ }^{\mathrm{a}}$ of right front leg bone weights and dimensions in Duroc gilts selected for different degrees of leg soundness.

\begin{tabular}{|c|c|c|c|c|c|c|}
\hline \multirow[t]{2}{*}{ Trait } & \multicolumn{2}{|c|}{ Low-line $(\mathrm{N}=14)$} & \multicolumn{2}{|c|}{ Control-line $\quad(\mathrm{N}=16)$} & \multicolumn{2}{|c|}{ High-line $(\mathrm{N}=14)$} \\
\hline & $\bar{X}$ & $S E$ & $\bar{X}$ & $S E$ & $\bar{X}$ & $S E$ \\
\hline \multicolumn{7}{|l|}{ Weight $(g)$} \\
\hline Scapula & 192.81 & 12.51 & 196.44 & 9.76 & 225.43 & 9.91 \\
\hline Humerus & 319.84 & 11.23 & 327.29 & 8.76 & 333.60 & 8.90 \\
\hline Radius and & 25080 & 926 & 24928 & 723 & 24949 & 734 \\
\hline Carpal bones & 60.62 & 2.94 & $\begin{array}{r}249.20 \\
64.35\end{array}$ & 2.29 & $\begin{array}{l}249.42 \\
5976\end{array}$ & 2.33 \\
\hline Metacarpal & & & & & & \\
\hline bones & 68.35 & 3.69 & 71.77 & 2.87 & 71.63 & 2.92 \\
\hline Phalanges & 78.75 & 3.70 & 81.16 & 2.93 & 83.00 & 2.91 \\
\hline \multicolumn{7}{|l|}{ Dimensions } \\
\hline $\begin{array}{l}\text { Scapula } \\
\quad \text { length }(\mathrm{cm})\end{array}$ & 18.86 & 0.28 & 18.92 & 0.22 & 18.41 & 0.22 \\
\hline $\begin{array}{l}\text { Scapula } \\
\quad \text { neck }(\mathrm{mm})\end{array}$ & $35.59^{\mathrm{d}}$ & 0.59 & $33.53^{\mathrm{e}}$ & 0.46 & $34.80^{\mathrm{d}}$ & 0.46 \\
\hline $\begin{array}{l}\text { Scapula } \\
\quad \text { thickness }(\mathrm{mm})\end{array}$ & $13.28^{\mathrm{f}}$ & 0.40 & $14.12^{\mathrm{f}}$ & 0.31 & $15.33^{\mathrm{g}}$ & 0.32 \\
\hline $\begin{array}{l}\text { Humerus } \\
\text { length }(\mathrm{cm})\end{array}$ & $19.22^{\mathrm{d}}$ & 0.45 & $19.20^{\mathrm{d}}$ & 0.35 & $17.76^{\mathrm{e}}$ & 0.36 \\
\hline $\begin{array}{l}\text { Humerus } \\
\text { head width }(\mathrm{mm})\end{array}$ & $39.78^{d}$ & 0.71 & $41.19^{\mathrm{de}}$ & 0.56 & $42.36^{\mathrm{e}}$ & 0.56 \\
\hline $\begin{array}{l}\text { Humerus head } \\
\text { angle (degrees) }\end{array}$ & $67.31^{d}$ & 0.89 & $67.35^{\mathrm{d}}$ & 0.70 & $70.38^{\mathrm{e}}$ & 0.71 \\
\hline $\begin{array}{l}\text { Radius } \\
\quad \text { length }(\mathrm{cm}\end{array}$ & 13.91 & 0.38 & 13.78 & 0.30 & 13.69 & 0.30 \\
\hline $\begin{array}{l}\text { Ulna } \\
\text { length }(\mathrm{cm})\end{array}$ & 19.95 & 0.27 & 19.43 & 0.21 & 19.05 & 0.21 \\
\hline $\begin{array}{l}\text { Metacarpal bone } \\
\text { length }(\mathrm{mm})\end{array}$ & $82.28^{\mathrm{f}}$ & 1.04 & $82.08^{f}$ & 0.81 & $77.49^{\mathrm{g}}$ & 0.83 \\
\hline
\end{tabular}

${ }^{a}$ Least squares estimates; ${ }^{\text {de }}$ Means within a row without a common superscript differ significantly $(P<0.05)$; ${ }^{\text {fg }}$ Means within a row without a common superscript differ significantly $(P<0.01)$.

et al, 1980; Wilson, 1980). Although Duroc pigs have been reported to have more severe osteochondral lesions of the front legs than other breeds (Goedegebuure et $a l, 1980 \mathrm{a}$; van der Wal et al, 1987), there have been no reports of a direct relationship between osteochondrosis and leg weakness in this breed of swine. Several investigators, however, have shown that there was no causal relationship between leg weakness and osteochondrosis in Duroc pigs (Goedegebuure et al, 1988; Draper et $a l, 1991)$. Our results seem to have supported these previous findings.

The significance of the differences of bone dimensions other than length was not clear. All dimensional changes in bone, other than length, occurred in the scapula and humerus, bones located above the level of the elbow joint and proximally within 
the front leg. There may have been some importance to this finding in that major line differences in soft-tissue structures were found below the level of the elbow in this and other studies (Draper et al, 1988; Draper et al, 1991). The wider head of the humerus of high-line pigs would have provided a greater surface area for articulation with the scapula. Similarly, the greater angle at which the head attached to the shaft of the humerus may have provided a more optimum relationship for articulation with the scapula. Collectively, the wider humerus head and greater humeral head angle, coupled with a thicker scapula, may have provided the best structure for freedom of movement of the shoulder joint and, thus, could have resulted in better front-leg movement and soundness in high-line pigs.

The differences observed in some bone lengths could have been related to differential growth patterns of the bones. This seemed unlikely, however, in that not all bones were affected and there were no differences in bone weights between lines. Furthermore, there were no line differences in general growth of the pigs.

Coinciding with bone-dimension changes were changes in muscle length and weight. Two muscles of the arm, the biceps brachii and tensor fascia antebrachii, were longer in low-line pigs and shorter in high- line pigs. This was not surprising in that both of these muscles are known to span the shoulder and the elbow joints (Sisson, 1975) (ie, their attachments extend from the scapula, span the length of the humerus, and end on the radius or forearm fascia). Thus, if the humerus was of different lengths in different lines of pigs, as was observed here, then it could have been anticipated that muscles that spanned the same distance as the humerus would have changed their length in accordance with length change of the humerus. For example, the humerus and biceps were $1.46 \mathrm{~cm}$ and $1.64 \mathrm{~cm}$ shorter, respectively, in high-line pigs than in low-line pigs. A similar explanation could be offered for the common digital extensor muscle. This muscle has attachments to the humerus and to the distal phalanges of the digits, thus spanning the distance from the level of the elbow joint to the distal part of the limb. The common digital extensor muscle was $1.86 \mathrm{~cm}$ shorter in high-line pigs than in low-line pigs, a distance that coincides with the combined length differences of the metacarpal bones and ulna in these same lines of pigs.

For muscle weight differences between lines, the biceps brachii was nearly $13 \mathrm{~g}$ heavier in low-line pigs than in high-line pigs. This muscle also was longer in low-line pigs than in high-line pigs. As expected, there was a positive correlation between muscle length and weight. The extensor muscles of the forearm were nearly $24 \mathrm{~g}$ heavier in low-line pigs than in high-line pigs. This finding was in agreement with previous work of the authors (Draper et al, 1991) in which they demonstrated that the total extensor cross-sectional area of the forearm was greater in low-line pigs than in high-line pigs. Most of the cross-sectional-area difference was because of the extensor carpi radialis. The same relationship was true for extensor-weight differences in this study in that more than $50 \%$ of this difference was because of the extensor carpi radialis. The muscle seems to have been a key structure that was changed as a result of divergent selection for leg weakness. The increased weight of the extensor carpi radialis and its larger cross-sectional area may have been related to activity of this muscle. This muscle functions as the most powerful extensor of the carpal joint. The carpal joint of low-line pigs has been reported to have a smaller resting angle and to have been more difficult to extend than in high-line 
pigs (Draper et al, 1988). Therefore, this muscle may have had to work harder than other forearm muscles to keep the carpal joint stabilized. Finally, because only a few specific muscles exhibited weight differences between lines, it was unlikely that there was any differential growth rate of muscles.

We hypothesize that there were probably structural differences in muscles and bones of the front leg between the three lines of pigs at the beginning of the selection experiment. These structural differences created biomechanical imbalance in the musculoskeletal structure resulting in leg weakness in low line pigs. We further hypothesize that continued selection for leg weakness for successive generations has exacerbated the structural differences between the three lines of pigs. Results from previous research showed that these differences were not related to osteochondrosis (Goedegebuure et al, 1988). However, there is evidence of a genetic association between increased leanness and leg weakness (Rothschild et al, 1988).

\section{CONCLUSION}

Based on the results of this study and previous investigations (Draper et al, 1988; Wang et al, 1990; Draper et al, 1991), it can be inferred that selection for different degrees of weakness has resulted in significant changes in bone and soft tissue structures. Most changes in bone occurred above the level of the elbow whereas most soft tissue changes occurred below this level. The increases in differences in bone and muscle were the cause of leg weakness. There is much to be gained by studying the biomechanics of locomotion and posture in the pig. Only in this way will producers know what is advantageous and thus be able to select pigs to reduce leg weakness. Musculoskeletal characteristics may need to be included in future selection criteria.

\section{ACKNOWLEDGMENTS}

The authors gratefully acknowledge the technical assistance of $\mathrm{J}$ Newton and $\mathrm{M}$ Braet. They also thank D R Berg (Humboldt University, Berlin) for assistance in isolating leg muscles.

\section{REFERENCES}

Bereskin B (1979) Genetic aspects of feet and leg soundness in swine. J Anim Sci 48, 1322-1328

Christensen ND (1953) Impotentia coeundi in boars due to arthrosis deformans. In: Proc 15th Int Vet Congr 15, 742-745

Draper DD, Rothschild MF, Christian LL, Goedegebuure SA (1988) Effects of divergent selection for leg weakness on angularity of joints in Duroc swine. J Anim Sci 66, 1636-1642

Draper DD, Rothschild MF, Christian LL (1991) Effects of divergent selection for leg weakness on bone and muscle cross sectional areas in Duroc swine. Am J Vet Res 52, 164-168 
Drewry KJ (1979) Production traits and visual scores of tested boars. J Anim Sci 48, 723-734

Duthie IF, Lancaster MC (1964) Polyarthritis and epiphysiolysis of pigs in England. Vet Rec 10, 263-272

Goedegebuure SA, Häni HJ, van der Valk PC, van der Wal PG (1980a) Osteochondrosis in six breeds of slaughter pigs. I. A morphological investigation of the status of osteochondrosis in relation to breed and level of feeding. Vet $Q 2,28-41$

Goedegebuure SA, van der Wal PG, van der Valk PC (1980b) Osteochondrosis in pigs. II. The relationship between the status of osteochondrosis and the degree of leg weakness. In: Proc 6th Int Pig Vet Soc Congr, Copenhagen, Denmark, p 326 Goedegebuure SA, Rothschild MF, Christian LL, Ross RF (1988) Severity of osteochondrosis in three genetic lines of Duroc swine divergently selected for front leg weakness. Livest Prod Sci 19, 487-498

Grøndalen T (1974a) Leg weakness in pigs. I. Incidence and relationship to skeletal lesions, feed level, protein and mineral supply, exercice, and exterior conformation. Acta Vet Scand 15, 555-573

Grøndalen T (1974b) Osteochondrosis and arthrosis in pigs I. Incidence in animals up to $120 \mathrm{~kg}$ live weight. Acta Vet Scand 15, 1-25

Grøndalen T (1974c) Osteochondrosis and arthrosis in pigs. II. Incidence in breeding animals. Acta Vet Scand 15, 26-42

Grøndalen T (1974d) Osteochondrosis and arthrosis in pigs. VI. Relationship to feed level and calcium, phosphorus, and protein levels in the ration. Acta Vet Scand 15, 147-169

Lawrisuk LS, Rothschild MF, Ross RF, Christian LL (1987) Relationship between Mycoplasma hyosynoviae infection and front limb weakness in Duroc swine. Am J Vet Res 48, 1395-1397

Nakano T, Aherne FX (1988) Involvement of trauma in the pathogenesis of osteochondrosis dissecans in swine. Can $J$ Vet Res 52, 154-155

Nielsen NC (1973) Arthrose hos svin. Nord Veterinarmed 25, 17-21

Reiland S, Ordell N, Lundeheim N, Olsson SE (1978) Heredity of osteochondrosis, body constitution and leg weakness in the pig. Acta Radiol suppl 358, 123-137

Rothschild MF, Christian LL (1988) Genetic control of front leg weakness in Duroc swine. I. Direct response to five generations of divergent selection. Livest Prod Sci $19,459-471$

Rothschild MF, Christian LL, Jung YC (1988) Genetic control of front leg weakness in Duroc swine. II. Correlated responses in growth rate, backfat, and reproduction from five generations of divergent selection. Livest Prod Sci 19, 473-485

Thurley DC (1969) Changes in the epiphyseal cartilage of immature pigs without clinical lameness. Pathol Vet 6, 217-228

Sisson S (1975) Porcine Myology. In: Sisson and Grossman's The Anatomy of the Domestic Animals (Getty R, ed) WB Saunders, Philadelphia 5th edn, p. 1263

van der Valk PC, van der Wal PG, Goedegebuure SA (1980) Osteochondrosis in pigs. I. The value of clinial symptoms in osteochondrosis. In: Proc 6th Int Pig Vet Soc Congr, Copenhagen, Denmark, p 325

van der Wal PG, Goedegebuure SA, van der Valk PC (1982) Leg weakness, osteochondrosis, and blood acid-base parameters in pigs. In: Proc 8th Int Pig Vet Soc Congr, Mexico City, Mexico, p 162 
van der Wal PG, Goedegebuure SA, van der Valk PC, Engel B, van Essen CE (1987) Leg weakness and osteochondrosis in pigs; differences between the sexes of four breeds. Livest Prod Sci 16, 65-74

Wang L-Y, Rothschild MF, Draper DD (1990) Comparison of body measurements in Duroc swine genetically different for severity of leg weakness. Acta Vet Zootech Sinica 21, 110-114

Webb AJ, Russel WS, Sales DI (1983) Genetics of leg weakness in performancetested boars. Anim Prod 36, 117-130

Wilson RD (1980) The effect of sire soundness classification and feed restriction on performance and leg scores of pigs. Ph D dissertation, Iowa State University, Ames, IA, $130 \mathrm{pp}$ 